\title{
TEACHER'S QUESTIONS IN ENGLISH CLASSROOMS AT SENIOR HIGH SCHOOLS
}

\author{
Andriyadi ${ }^{1}$, Dedi sofyan ${ }^{2}$, Azwandi $^{3}$ \\ English Education Postgraduate Program \\ Bengkulu University, Indonesia \\ E-mail : Andriyadi461@gmail.com
}

\begin{abstract}
The aim of this research was to investigate teacher's questions based on the levels and functions of questions in English classrooms at Senior High Schools. The study was a descriptive qualitative. The subjects of this research were six English Senior High School teachers In Rejang Lebong Regency. For collecting the data tape recording, observation checklist and interview were employed. Result related to research questions showed that the teacher's questions were categorized remembering, comprehending and applying and analyzing level. None of the teachers used questions in, evaluating and creating level of the Bloom's Taxonomy. In the research only five function of questions were found namely: practicing skills, checking prior knowledge, recapping, and checking understanding. From the finding it can be concluded that The questions asked by the teachers in classrooms are in lower order cognitive level and not all function of questions (from eleven function of questions) were applied by the teachers.
\end{abstract}

Keywords: Teacher's Questions, English Classrooms, level and function of questions. Senior High Schools

\begin{abstract}
ABSTRAK
Penelitian ini bertujuan untuk menginvestigasi pertanyaan guru berdasarkan level dan fungsi pertanyaan pada proses pembelajaran Bahasa Inggris di dalam kelas Sekolah Menengah Atas (SMA ). Jenis penelitian ini adalah deskriptif qualitatif. Subyek penelitian ini adalah enam orang guru Bahasa Inggris SMA di Rejang Lebong. Rekaman, observation checklist dan wawancara digunakan dalam pengambilan data. Hasil penelitian yang berhubungan dengan pertanyaan menunjukan bahwa pertanyaan-pertanyaan yang tanyakan oleh guru dikatagorikan pada level remembering (mengingat), comprehending (memahami), applying (menerapkan) dan analyzing (menganalisis). Tak satupun guru pertanyaan guru pada level level evaluting (evaluasi) dan creating yang merupan level tinggi pada taxonomy Bloom. Pada research ini ditemukan hanya lima fungsi penggunaan kalimat tanya yaitu : factual elicitation (pengulangan fakta), practicing skill (melatih keterampilan) checking prior knowledge (mengecek pengetahuan), recapping (menyusun ulang), dan checking understanding (memeriksa pemahaman). Berdasarakan penelitian ini dapat disimpulkan bahwa pertanyaan-pertanyaan yang ditanyakan guru di dalam kelas digolongkan pada level kognitif rendah dan tidak semua fungsi pertanyaan (dari sebelas fungsi pertanyaan) diterapkan oleh guru.
\end{abstract}

Kata-kata Kunci: Pertanyaan guru, Pembelajaran bahasa Inggris, Level dan fungsi pertanyaan, Sekolah Menengah Atas 


\section{INTRODUCTION}

Indonesia applied the Curriculum 13 (C-13) since 2014. the C-13 applies scientific approach as its ways of teaching and learning activity. This approach has five ways of thinking to arrive at the truth (knowledge) namely observing, questioning, experimenting, associating and networking (Depdiknas, 2014). The C-13 covers broad content and cognitive aspect, not on the essental aspects that will enable students to be critical and be able to participate in the global world to support Indonesia in the upcoming years. Additionally, the new curriculum also offers the building of character to prepare the students to face various opportunities, which could bring both positive and negative sides to students and society in general. Character education gives the students the knowledge they need to know especially concerning the negative effects of the advancement of technology, science, and art and how they could deal with them properly.

However, English teaching in Indonsia is still not successful. . This is can be seen from the result of English exam in National Examinations.

One of the possible factors that influence this is teacher's teaching technique. Teacher teaching technique holds a very crucial role in teaching. Teacher's question is one of the aspect that is very important. Dillon (1988) claims that teacher's questioning plays a very important role to initiate classroom talk. Questions can stimulate students' motivation, focus their attention, help students learn and think better, and also help the teacher know how well a student's learning is. In addition, Gall (1984) argues that one manifestation of teacher talk is teacher question.

In teaching and learning process, teacher usually ask some questions to student. Teacher's question is crucial factor to initiate student to talk in classroom. Asking questions in teaching and learning activity is a way to stimulate students to participate and involve them in language classroom activities. Asking questions in classroom used to make students actively participate in language classroom activities. Asking questions of this activities is known as teacher's question. The teacher must simulate the students to thinks critically by answer the teacher' questions.

According to Cotton (1988) teacher questions are defined as instructional cues or stimuli that convey to students the content elements to be learned and directions for what they are to do and how they are to do it.

Clottu (2017) investigates the complexity of the different contexts as well as the diversity of professionals' questions. The result of this study found students speak diverse languages and attend the courses of regular schools near their homes, this original design takes place in an inclusive context and aims at enabling the teachers to develop reflective practice. 
Tamas Kiss at all (2012) studied Investigating Teacher Questions Within the Framework of Knowledge Building Pedagogy. The researcher found the implementation of Knowledge Building pedagogy has a positive impact on teacher questioning and contributes to creating an effective learning environment.

Al-Zahrani (2017) studied the effect of questions on fostering interaction in English as a Foreign Language (EFL) classrooms. It also seeks to determine the characteristics of questions that promote increased classroom interaction in Saudi Arabia. Results showed a correlation between the qu estions' characteristics and the creation of classroom interaction. In other words, some question types significantly improved classroom interaction while others failed to do so.

Based on studies of teacher's question by several investigator, such as Clottu (2017), Tamas at all (2012) and Al-Zahrani (2017). They had concerned on topic about: the form of questions, the implementation of Knowledge Building pedagogy in questions and the effect of questions on fostering interaction in English as a Foreign Language (EFL). However, The level of the teacher's questions have never been conducted. This motivation of the researcher to investigate the level of the teacher's questions and student's respond of The Senior High School in Rejang Lebong.
This primary questions adressed in this study are follows:

1. What level of questions do English teachers ask in English classes at Senior High Schools in Rejang Lebong Regency?

2. What are the functions of the questions asked by the English teacher in classroom?

\section{METHOD}

Corpus of the Study

This research investigated the teacher's question in classroom employed by the teacher along with the English teacher's. This research is a descriptive research. Descriptive research is used to describe characteristics of a population or phenomenon being studied. It does not answer questions about how/when/why the characteristics occurred. Rather it addresses the "what" question (what are the characteristics of Minnesota state population or situation being studied?). (Shields, Patricia and Rangarajan, N. 2013). Descriptive research is a study designed to depict the participants in an accurate way. More simply put, descriptive research is all about describing people who take part in the study. It is considered suitable to present the fact related to the problem which are going to be discussed. Qualitative research is a broad methodological approach that encompasses many research methods, and special education and education searchers. 
The research aims to analyze the teacher's question in classroom of Senior High Schools in Rejang Lebong

\section{Data Analysis Procedures}

There were several steps conducted in analyzing the data collected in this research since the data were also collected through several instruments. The data had taken from the observation checklist, recording and interview.

The first data analysis conducted was data analysis from observation checklist. The data collected from observation when the teachers were teaching in classroom. The observation checklist was used to classify the level of questions and function of questions.

\section{FINDING AND DISCUSSION}

This chapter present the result of the data collection through recording, classroom observation checklist and interview and for the teachers. The data analyzed in two main parts which were the level of questions and the function of questions from the teacher's questions in classroom.

This chapter present the result of the data collection through recording, classroom observation checklist and interview and for the teachers. The data analyzed in two main parts which were the level of questions and the function of questions from the teacher's questions in classroom.

discussed based on each level of teacher's questions and function of questions in classroom.

\section{1. The Level of Question}

The data combined on one table. The result of observation and recording are presented in table 4.1 bellow.

Table 1: The Level of Question

\begin{tabular}{|l|l|c|}
\hline NO & \multicolumn{1}{|c|}{ Level of Question } & F (\%) \\
\hline \multicolumn{2}{|l|}{ A. Low Order Thinking } & $11(18,64 \%)$ \\
\hline 1 & Remembering & $32(54,24 \%)$ \\
\hline 2 & Comprehending & $8 \quad(13,56 \%)$ \\
\hline 3 & Applying & $8(13,56 \%)$ \\
\hline B. High Order Thinking & - \\
\hline 4 & Analyzing & - \\
\hline 5 & Evaluating & $\mathbf{5 9 ( 1 0 0 \% )}$ \\
\hline 6 & Creating & \\
\hline Total & Questions
\end{tabular}


the table shows that there are 59 questions from six level questions based on the Bloom's taxonomy. 11 ( $18,64 \%)$ questions were categorized remembering level. 32 (54, 24\%) questions were categorized comprehending level. The use of applying level are $8(13,56 \%)$. that there are not questions in level evaluating and creating.

$8(13,56 \%)$ questions were categorized analyzing level.

The table shows The table shows the function of question. 59 question had categorized based on each function. 9 $(15,25 \%)$ were Factual elicitation function. $14(23,73 \%)$ were practicing skills function. $12 \quad(20,34 \%)$ were checking prior knowledge, 11 (18,64\%) recapping function and 13 (22,03\%) checking understanding function

All questions of the data above are categorized based on their level questions and their functions The data of the dialogue between the teachers and their students can be seen on the transcript bellow.

\subsection{Remembering}

The learner's ability to retain and recall information. This usually comes in the form of recognition, retrieving, or listing.

\section{Example:}

Teacher : Good morning class.

Students: Fine.
Teacher : Good. Thank you.

Teacher : For to day before continue our lesson I want to ask you did you remember what was our last material? ${ }^{(1)}$

Students : Past tense.( Tense in past form).

Teacher : What is our assignment? ${ }^{(2)}$ Students : No.

The question 1 on the dialogue "what was our last material?" show that the teacher recalled or retrieved previous learned information from the last days. $\mathrm{He}$ recognized or recalled knowledge from the student's memory. The question was used to begin the lesson. It had function to recite previously learned information. From the question the students remembered the previous material by giving respond "Past tense."( Tense in past form). The question connected to the last material and the material was being studied at the time. Question 2 "What is our assignment?" was used to explore the last information from the previous activities in learning. The student answered "No", they remembered that the teacher did not give them assignment after discussing the material.

\subsection{Comprehending}

Requires that the learners explain the situation or process in order to show that 
they have understood the materials. This usually involves summarizing,

paraphrasing or detailed descriptions.

\section{Example:}

Teacher : Good morning class.

Students : Fine.

Teacher : Good. Thank you.

Teacher : For today Before continue our lesson I want to ask you did you remember what was our last material ? ${ }^{(1)}$ What is our assignment? ${ }^{(2)}$

Students : Past tense.

Teacher : OK about nominal sentence and verbal sentence, Do you have trouble? ${ }^{(3)}$

Students : No.

Teacher : Any trouble? ${ }^{(4)}$

Students : No.

Teacher : Ok, Is clear about past tense in the sentence? Using verb two, using this, and than what else? (5)

Students : No.

Teacher : Do you have question $?^{(6)}$

Students: No.

Question 3 and 4 "Do you have trouble,?" and "Any trouble?" indicated that the teacher checked the student's comprehending. The level of questions were categorized comprehending level.The questions related to the teacher's explanation. The data show that the students understand the material.
Question 5 and 6 "what else?" and "Do you have question?" show that the questions constructed meaning from material. The teacher asked the students to review the material.

The example shows that there are 3 comprehending questions from the teachers. Question 1, 2 and 3 are used to check the student's comprehending. These questions focus on what did the student understand on the lesson. On the data shows that all students understand all material. The student's responds "No" indicated that they recognized the material.

\section{Applying}

This asks learners to use information that they already have gained, in order to solve a problem that may be similar in nature. This involves implementation of prior knowledge and skills.

Example :

Teacher : Good morning class.

Students: Good morning.

Teacher: How are you today?

Students: Fine thank you, and you?

Teacher: What is a sentence $?^{(1)}$ Who want to try to answer? ${ }^{(2)}$

Students: -

Teacher; A sentence is a group of word which it has minimal has a subject and verb. Sentence. Dived of two kind of sentence. Nominal sentence and verbal. 
In what way we use of simple past tense ?(3) $^{(3)}$

Students : Untuk mengingat waktu.

Teacher: Yeah to show the incident activity which happen in past time. For nominal sentence. Who want to try to give the example about nominal in simple past sentence, please? ${ }^{(4)}$

Students : OK Mom

Teacher : Who want to try to change the sentence from present tense to past tense? for example they are my cats. Ok. Please change into paste. Who want to try to write on white board? ${ }^{(5)}$, Indah please!

Student : OK.

Teacher : Jadi yang ubah darin present ke past adalah to be jika nominal. Jika verbal yang diubah. Jadi yang are become were. OK. very good.

The first question Who want to try to answer?" was used to make the student's respond. The teacher asked the students to apply their ability in giving the definition of a sentence based on their knowledge.

The second Who want to try to answer?" indicates that the teacher asked the student to try to give their answer about the meaning of a sentence or definition of a sentence.

The third question of the dialogue In what way we use of simple past tense? indicates that the teacher gave more specific question about the using of simple past tense. This question applied to relate with the first and the second questions. The teacher gave the question after the students were able to answers the first and the second questions.

The fourth question "Who want to try to give the example about nominal in simple past sentence, please?" shows that the teacher asked the student to apply in making a nominal in simple past sentence. It was an implementation of the student's ability.

The fifth question " Who want to try to write on white board? ${ }^{(5)}$, Indah please! Indicates that the teacher asked the students to apply their ability to write a nominal in simple past sentence on white board. From the sentence the teacher knew the student understood or not.

\section{Analyzing}

In this process, learners will have to break down the data that was provided in order to fully grasp the content (as it is now in more manageable parts). This usually requires learners to use comparative and/or deconstruction skills.

\section{Example}

Teacher: How about the second picture $?^{(1)}$

Students: Announcement menggunakan mix.

Teacher: Observe this! How do you thing for this announcement? ${ }^{(2)}$, Is announcement or written announcement? ${ }^{(3)}$

Students : Lisan.

Teacher: What does the announcement talk about here? (4) Tentangapa pengumuman itu. 
Students : Besok pagi siswa diharapkan bawa topi dan dasi.

Teacher : And now please you observe announcement one and two! Oral and written announcement. What is the different announcement here? ${ }^{(5)}$

these

Students : Kalau tertulis ditulis lisan diucapkan.

Teacher : OK. for conclusion. What tense the writer use to write the announcement? (7)

Students : Simple present tense.

"How about the second picture?" in question 1 was categorized in analyzing level. The students must analyzed a picture before answering it. All facts of the picture were described by their own words. On the data students answered the question by Indonesia and English.

"How do you thing for this announcement? In question 2 indicates that the teacher asked the students to give their opinion in responding the question. The student responded by saying "Lisan" (oral announcement). that the students need to analyzed the announcement before giving their They responded based on their analyzed the picture.

The question 5 "What does the announcement talk about here?" shows responds. They must observe the announcement. "Besok pagi siswa diharapkan bawa topi dan dasi" was the student's respond. It means that they understood the teacher's question although the respond was in Bahasa Indonesia.

The question 6 "What are the different these announcements here?" was the analyzing question where the students gave respond by differentiating between two announcements. They compare that announcements. Before giving their respond they observed, analyzed and decided to what they would say.

What tense the writer use to write the announcement? In question 7 shows the aim of teacher's question was to test the student's knowledge of tense. The question was correlated to tense which used in the sentences of announcement.

\section{The Function of Question}

Myhill,D (2006) in which teacher's question are categorized into 11 functions namely; class management, practicing skills, checking prior knowledge cued elicitation, developing vocabulary, recapping, checking understanding, building on content, building on thinking, and developing reflection, as shown in table. 
Table 2: The level of Function of Questions

\begin{tabular}{|l|l|}
\hline Function of Question & F \% \\
\hline Factual elicitation & $9(15,25 \%)$ \\
\hline Class management & - \\
\hline Practicing skills & $14(23,73 \%)$ \\
\hline $\begin{array}{l}\text { Checking prior } \\
\text { knowledge }\end{array}$ & $12(20,34 \%)$ \\
\hline Cued elicitation & - \\
\hline Developing vocabulary & - \\
\hline Recapping & $11(18,64 \%)$ \\
\hline $\begin{array}{l}\text { Checking } \\
\text { understanding }\end{array}$ & $13(22,03 \%)$ \\
\hline Building on content & \\
\hline Building on thinking & \multicolumn{1}{|c|}{$\mathbf{5 9 ~ ( 1 0 0 \% )}$} \\
\hline Developing reflection & \\
\hline
\end{tabular}

\section{Factual elicitation}

Teacher : Good. Thank you. For today Before continue our

Factual elicitation is to structure a lesson by, so to speak, hopping from a question to the next one, using the learners' answers as point of departure for the next question. To follow his or her plan, the teacher can not proceed with the lesson until the expected answer is given by a learner. This approach can be referred to as elicitation method“ (Nunan 1991, 195).

\section{EXAMPLE}

Teacher : Good morning class. Students : Fine. lesson I want to ask you did you remember what was our last material?" (1) What is our assignment? ${ }^{(2)}$,

Students: Past tense."

Question 1 "what was our last material?" and 2 What is our assignment?" were elicitation function The questions above were to recall information about the last lesson. The teachers asked the question before giving the material. The questions were as ways review the previous 
material. It was used to begin the new material.

Teacher : How are you this morning?

Students: Fine.

Teacher : OK. What was our lesson? ${ }^{(1)}$

Students : Famous people.

Teacher : Apa pelajaran terakhir kemaren? What Chapter? ${ }^{(2)}$ Famous people? ${ }^{(3)}$

Students: Yes.

The teacher recalled students about the previous material by Asking student some question such as "What was our lesson?", What Chapter?" and "Famous people?" The questions were used to remember the last material.

\section{Practicing skills}

Students are expected to rehearse, repeat or practice a strategy or understand something. Students practice to express their idea or comprehending by answering questions.

\section{Example:}

Teacher : Who want to try to answer?

Students : -

Teacher: Yeah to show the incident activity which happen in past time. For nominal sentence. Who want to try to give the example about nominal in simple past sentence, please?" (1)

Students : -
Teacher : Who want to try to change the sentence from present tense to past tense? ${ }^{(2)}$ for example they are my cats. Ok. Please change into paste. Who want to try to write on white board? (3) Indah please.

Students : OK. Mom

Teacher : who want to try to make negative form from sentence l ate banana?

Students : I did not ate banana.

Based on the recording were found that the teacher who produced two practicing skills. The question are 1. Who want to try to change this sentence from present tense to past tense 2. who want to try to make negative form? The data above shows the teacher asked the students to try to change the sentence from present tense to past tense (in question 1) and to try to make negative form (in question 2). All the questions indicate the students were expected to rehearse, repeat or practice a strategy or understand something.

\section{Checking prior knowledge}

Prior knowledge is an essential part of the meaning making negotiated between interlocutors. In classrooms, 
too, students' prior knowledge is a key factor in students overall achievement and performances. It related to check knowledge and experience relevant to lesson.

\section{Example}

Teacher: How are you this morning?

Students: Fine.

Teacher: OK. What was our lesson?

Students: Famous people."

Teacher: Have you heard about Louis Pasteur?

Students: Yes.

From the recording was found that there a teacher who produced one checking prior knowledge.. The question was "have you learn about Louis Pasteur?" Based on the data that the question from the teachers was related to checking knowledge and experience relevant to lesson. The teacher connected the last lesson that have studied to the lesson at the time.

\section{Recapping}

Recapping means students
repeat the main points of an
explanation or description. Students
recall prior lessons and work done in
this lesson.

\section{Example}

Teacher : How are you this morning?

Students: Fine.

Teacher : Do you still remember what is biographical recount? ${ }^{(1)}$

Students : Biographical belong to recount text.

Teacher: What is the function of biographical recount? (2)

Student : Biographical written by series of person life.

On the recording was found that there a teacher who produced one recapping. The question is do you remember what is biography recount?

The question on the data was recapping. The teacher tried to refresh the student's memory about the last lesson and to connect with the lesson were being studied.

\section{Checking understanding}

Questioning is the predominant tool for determining what students know. It is important to recognize that what is done with the question is essential. It relate to check grasp of ideas and concepts already covered

\section{Example:}

Teacher : Find out what happen on the picture?

Student : -

Teacher : Is it clear? ${ }^{(1)}$

Student : "Yes.

Teacher : Do you have trouble? ${ }^{(2)}$

Students : No.

Teacher : any trouble? ${ }^{(3)}$

Students : No. 
Teacher: Ok, Is clear about past tense in the sentence? (4) Using verb two, using this, and than what else?

Students: No.

Teacher : Do you have question ${ }^{(5)}$

Students: No.

Question 1, 2, 3 and 5 indicate the teacher checked the student's understanding about the material of the lesson. Question 4 shows that the teacher checked the student's understanding by saying the material of the lesson.

\section{Result of Interview}

The result of the data collection through classroom interviews are presented in the interview transcript bellow:

Example:

Interviewer: Do you know the Bloom's taxonomy?

Interviewe : Yes.

Interviewer: In Bloom's taxonomy there are five levels namely remembering, comprehending, applying, analyzing, evaluating and creating? According to you which levels are difficult to apply in asking questions?

Interviewee: In my opinion, the difficulty of using level defends on the class of students. Different class are not same in applying the level. Evaluating and creating are difficult level.
Interviewer : Do you know the function of questions?

Interviewee : Yes.

Interviewe : Do you consider the function of questions before you ask students some questions?

Interviewee : Yes. I must correlate my questions with the student's respond

Interviewer : What are the function of your questions?

Interviewee : to know the students understand or not the lesson.

The transcript above shows that not all level of questions were applied by the teacher in classroom. The use of level of question were not same to all class. Evaluating level and creating level were difficult to apply in classroom. It mean that the teacher did not use the levels.

The interview shows that the Interviewee did not know all function of question. She only mention one function of her question as this sentence "to know the students understand or not the lesson." She did not the other function of questions.

\section{Result of Checklist Observation}

The finding from checklist Observation regarding teacher's questions in classroom were presented in table 4.2. Overleaf

Table. 4.2: Checklist Observation (Level of Question) 


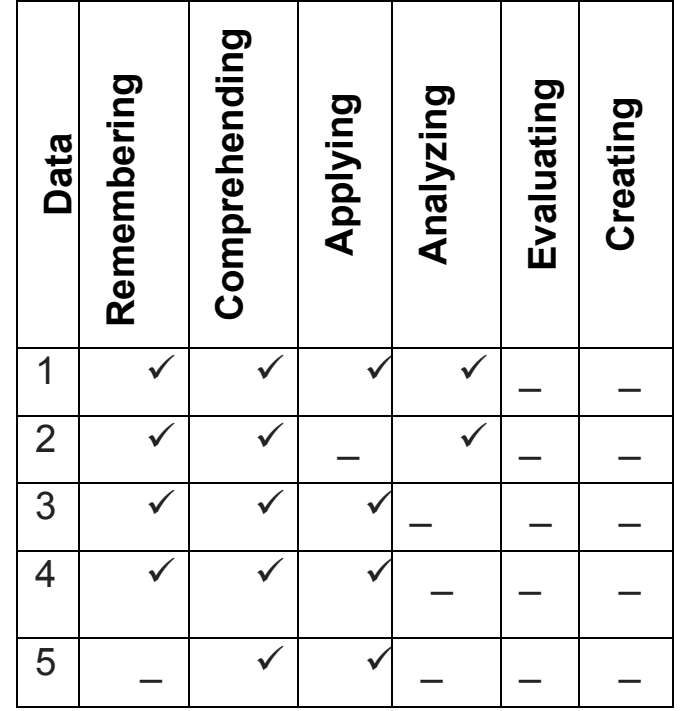

The table show that four teachers applied remembering level in asking questions in classrooms. Only one teacher did not applied it. All teachers applied remember levels when they were asking students some questions in classroom. Three teachers applied teachers applied analyzing levels in their students in classrooms. Two asking applying level to ask some questions students some questions and three teachers did not applied it. No one teacher who applied evaluating and creating levels when they were asking some questions in classroom.

Table 4.3: Checklist Observation( Function of Question)

\begin{tabular}{|c|c|c|c|c|c|c|c|c|c|c|c|}
\hline \multicolumn{12}{|c|}{ FUNCTION OF QUESTION } \\
\hline$\underset{\mathbb{S}}{\stackrel{4}{6}}$ & 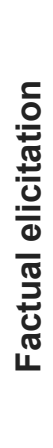 & 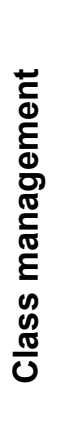 & 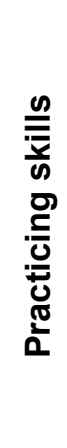 & 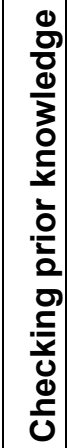 & 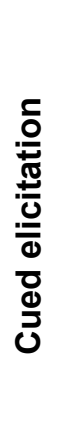 & 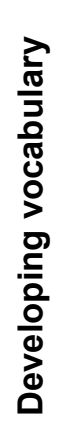 & 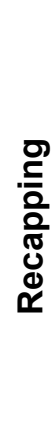 & 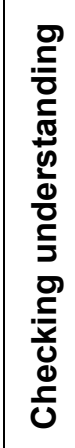 & 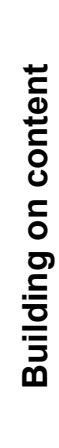 & 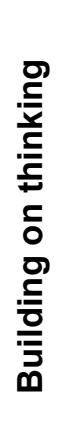 & 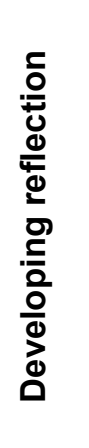 \\
\hline 1 & $\checkmark$ & - & - & $\checkmark$ & - & - & $\checkmark$ & $\checkmark$ & - & - & - \\
\hline 2 & $\checkmark$ & - & $\checkmark$ & $\checkmark$ & - & - & $\checkmark$ & $\checkmark$ & - & - & - \\
\hline 3 & $\checkmark$ & - & - & $\checkmark$ & - & - & $\checkmark$ & $\checkmark$ & - & - & - \\
\hline 4 & $\checkmark$ & - & $\checkmark$ & $\checkmark$ & - & - & $\checkmark$ & $\checkmark$ & - & - & - \\
\hline 5 & - & - & $\checkmark$ & - & - & - & - & - & - & - & - \\
\hline
\end{tabular}


The table show that factual elicitation function applied by four teachers to asks students some questions in classroom. There were not who applied class management level. Three teacher were applied Practicing skills level. Only one teacher did not applied Checking prior knowledge level. There were not teachers who applied Developing vocabulary, Building on content, Building on thinking and Developing reflection level. Four teachers applied Recapping and one teacher did not applied it. Checking understanding was applied by four teachers and one teacher did not applied it.

\section{Discussion}

\section{The Level of Teacher's Question}

The first question in this research was what level of questions do English teachers ask in English classes at Senior High Schools in Rejang Lebong Regency. From the result above, the teacher used 32 questions $(54,24 \%)$ at comprehending level. 11 questions ( $18,64 \%)$ are remembering level and 8 questions (13,56\%) are applying level. There were not teachers used questions in evaluating and creating level of the Bloom's taxonomy. The majority of teachers used questions in comprehending level at the classroom. Comprehending is the second level of low order thinking in the Bloom's taxonomy. Based on the theory at the level contents comprehending the meaning, translation, interpolation, and interpretation of instructions and problems. State a problem in one's own words.

The result show that the using question were majority in low level of questions. The high levels of questions (evaluating and creating did not apply in teacher's questions.From the table known 32 (54, 24\%) questions were categorized comprehending level. It means that the teacher the using of comprehending level were dominantly in asking question, in the other hand, 8 $(13,56 \%)$ questions were categorized analyzing level. It indicates that the higher level were difficult to apply in classroom.

The previous study was conducted by Jannah (2013) entitled An Analysis of Teacher's Question In EFL Classroom. She found that only four of all cognitive domains of Bloom's question taxonomy were asked by the teachers especially in three lower cognitive level namely; remembering, comprehending and applying or those are in some displays 
questions and one of three higher cognitive levels such as analysis. Furthermore, the study revealed that the questions or cognitive levels would not make students produce longer responses unless the teachers are able to encourage the students their students to elaborate further rater that just accepting responses brief or less complex responses.

The result was suitable with Ping Shen's study. He found that the teachers asked more lower-cognitive questions $(79.2 \%)$ than higher ones $(20.8 \%)$. Based on the theory of the cognitive domain, results revealed that excessive use of lower-cognitive questions could not facilitate the development of students' critical thinking. Additionally, the misuse of higher-cognitive questions by the teacher was also identified. The previous research had the similarity with this research. The both researches show that the majority of teachers asked more lower-cognitive questions. The questions could not facilitate the development of students' critical thinking. The cognitive domain involves knowledge and the development of intellectual skills (Bloom, 1956). Based on the theory that the questions could not reach the high cognitive. They could not develop the students' critical thinking. Based on the cognitive domain theory, the most important thing is that high cognitive question (HCQ) can promote students' higher-order thinking. $H C Q$ can require students to engage in independent thinking such as problem solving, analyzing and evaluating information. Two previous studies above had similarity with this research where the teachers did not applied the high cognitive question . Based on the result that the teachers did not use evaluating and creating level when they were asking some questions to students. There were not teachers used the operational verbs of evaluating and creating level. The action verbs for evaluating level are namely: judge, select, decide, justify, verify, argue, recommended, assess, discuss, determine and choose. There were not the action verbs for creating level such as: change, estimate, make, compile and adapt in the research .Evaluating involves making judgments based on criteria and standards through checking and critiquing.

Critiques, recommendations, and reports are some of the products that can be created to demonstrate the processes of evaluation. In the newer taxonomy, evaluating comes before creating as it 
is often a necessary part of the precursory behavior before one creates something. Creating are putting elements together to form a coherent or functional whole; reorganizing elements into a new pattern or structure through generating, planning, or producing. Creating requires users to put parts together in a new way, or synthesize parts into something new and different creating a new form or product. This process is the most difficult mental function in the new taxonomy.

The teacher's questions were not able to motivate students to reach the high order thinking, the teachers did not use the level because the students were lack of vocabularies. They got difficulty to answer the questions using the levels. The results showed that the teachers asked more low cognitive questions related to recalling facts or grasping main contents of materials, especially knowledge, than high cognitive questions. The results of this research revealed the limited use of high cognitive questions would limit the development of students' CT. Furthermore, the weakness of teacher's questioning behavior was identified. A few of HCQ from the teacher, in lacking a chain of reasoning and explicit instruction, could not prompt the development of CT either. The result of interview shows that some teachers did not apply the high cognitive level caused by several reasons such as the students had lack of vocabulary. Some teachers felt that their student were anxious to answers the questions. They thought that they useless asks some questions using the evaluation and creating level so that the students did not have chance involves making judgments based on criteria and standards through checking and critiquing. Furthermore, the students could not solve their our problem to improve their weakness in speaking, they could not contribute too much to run their lesson. The teacher did not encourage students to estimate, plan and find the solution about the lesson. Therefore, The study recommends that teachers are expected to focus on $\mathrm{HCQ}$ after asking a series of $L C Q$ in order to give an environment rich in opportunity for enabling CT. Moreover, teachers should be trained how to ask some questions appropriately and effectively, especially $\mathrm{HCQ}$. 
2. The functions of Teacher's questions

Eleven functions of question could be applied in the classroom. They were factual elicitation, practicing skills, checking prior knowledge recapping, and checking understanding class management, practicing skills, checking prior knowledge, cued elicitation, developing vocabulary, recapping and checking understanding. In the research only five questions were applied when they were asking questions in classroom, namely; factual elicitation, practicing skills, checking prior knowledge, recapping, and checking understanding.

Not all functions of question applied in the classroom. They were developing vocabulary, building on content, building on thinking, cued elicitation, building on content and developing reflection

Based on the data was found that the teachers did not apply all function of the sentences. Almost the teacher's questions could be responded by the students on the data. The student's respond were suitable with the questions. student's respond were spoken in English. Several respond were spoken in Bahasa Indonesia.
The result shows that practicing skills function. 14 questions $(23,73 \%)$. It means that the teachers majority used question as practicing skills function in asking questions. 9 $(15,25 \%)$ were Factual elicitation function. The using of practicing skills function are suitable with curriculum 13 (C13) where students are dominantly active in all activities. Teachers are as facilitator.

The result above was different with Myhill D (2006). He found The dominant forms of statements were informing and instructing, and the dominant form of questions was factual. This suggests a pattern of teaching which is trans missive, with the teachers in this study imparting factual information, and asking factual questions. The teachers appear to be the givers of information, the children the receivers. The differences were caused by the level of student's. The subject of Myhill D were students of Elementary school and this subject of this research were students of Junior High School. The level of age influenced the teachers in giving questions.

One feature the analysis highlights is the relatively low number of questions relate to higher-order 
thinking, those questions which 'promote reflection, analysis, selfexamination and enquiry' (Wood, 1988). Based on the theory that building on thinking function and developing reflection were higherorder thinking where students had chance to move forward with students' ideas and concepts and query how pupils are learning and the strategies they are using. From the result was found that the function of teacher's questions were categorized in higher-order thinking. The result of interview were relevant with the result of recording where not all function of question were applied by the teacher. Based on interviews only five function question applied in classroom namely; factual elicitation, practicing skills, checking prior knowledge, recapping and checking understanding. The teacher did not applied the other function of questions such as: class management, cued elicitation, Cued elicitation, building content, building thinking and developing reflection. The teacher should applied them in asking some questions in classroom. Class management means the teacher linked to management of student's tasks/behavior. Cued elicitation function gave them to cue answering. Developing vocabulary meant the teacher's question posed students to assess or clarify understanding of vocabulary. Building on content function made students to put together information about the topic of the lesson. Building on thinking gave chance the students to move forward with their ' ideas and concept of leaning. Developing reflection querying how pupils are learning and the strategies they are using. Developing reflection query how pupils are

\section{CONCLUSION}

Based on problems formulated in chapter 1, two things are concluded in this research. The first about the level of teacher's questions asked by the English teachers in English classroom, the second about the function of teacher's question in classroom. The conclusion are explained as follows:

\section{The level teacher's questions.}

The majority of questions asked by the teachers were lower order cognitive thinking levels questions. There were remembering, comprehending and applying. There were not teacher 
applied evaluation and creating level

when they were asking questions in classroom.

\section{The function of teacher's questions.}

English teachers applied five function of questions when they were asking questions namely: factual elicitation, practicing skills, checking prior knowledge recapping, checking understanding class management, practicing skills, and checking prior knowledge,

\section{REFERENCES}

Alison, K. (1994). Guiding knowledge construction in the classroom: Effects of teaching children how to question and how to explain. American Educational Research Journal, 31(2), 338-368.

doi:10.2307/1163313

Almeida, P. A. (2010). Questioning patterns, questioning profiles and teaching strategies in secondary education. International Journal of Learning, 17(1), 587-600

Andrews, J. D. W. (1980). The verbal structure of teacher questions: Its impact on class discussion. POD Quarterly: The Journal of the Professional and Organizational Development Network in Higher Education. Paper 32.

Anderson, J. R. (2004). Cognitive psychology and its implications (4th ed.). New York: W.H. Freeman and Company.

Answerbaghttp://www.answerbag.com/q _view/2442807\#ixzz30XJX34 cf

Bloom, Benjamin (ed). Taxonomy of Educational Objectives. Vol. 1: Cognitive Domain. New York: McKay, 1956.

Boas, Franz (1943). "Recent anthropology". Science. 98: 311-314, 334-337. doi:10.1126/science.98.2546. 334

Broadbent, D. E. (1958). Perception and communication.

Oxford: Oxford University Press.

Brown, H. D. (2001). Teaching by Principles: An interactive approach to language pedagogy. New York: Addison Wesley Longman, Inc.

Brown, H. (2006). Teaching by Principles: An interactive approach to language pedagogy. New Jersy: Prentice Hall Regents. In W. C. Wu (Ed.). Chaiklin

Carin, A. A., Bass, J. E., \& Contant, T. L. (2005). Teaching science as inquiry (10th ed.). Upper Saddle River: Merrill/PrenticeHall.

Clottu Régine (2017) Training design conception and reflexive practice: how to answer teachers' questions? Universal Journal of Educational Research 5(3): 386-395, 2017 
http://www.hrpub.org DOI: 10.13189/ujer.2017.050311

Cotton, K (1988) Monitoring student learning in the classroom. Portland, OR: Northwest Regional Educational Laboratory,

Dallimore, E. J., Hertenstein, J. H., Platt, M. B. (2012). Impact of coldcalling on student voluntary participation. Journal of Management Education, 37(3).

Eka Raudhatul Jannah (2013). An Analysis of $A$ Teacher's Questions in EFL Classroom. Universitas Pendidikan Indonesia

Gamoran, A, and Nystrand, M. (1997) Opening dialogue: understanding the dynamic of language and learning in the English classroom. New York: Teacher Collage Press.

Hamre, B. K., Pianta, R. C. (2001). Early teacher-child relationships and the trajectory of children's school outcomes through eighth grade. Child Development, 72, 625-638. Google Scholar, Crossref,

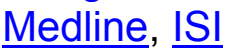

Harlen, W., \& Qualter, A. (2004). The teaching of science in primary schools (4th ed.). London: David Fulton Publishers.

Henricsson, L., Rydell, A. (2004). Elementary school children with behavior problems: Teacher-child relations and self-perception. a prospective study. Merrill-Palmer
Quarterly, 50, 111-138. Google Scholar, Crossref, ISI

Richards, J. et.al. (1996). Longman dictionary of language teaching and applied linguistics. Essex: Longman

Shields, Patricia and Rangarajan, N. 2013. A playbook for research methods: integrating conceptual frameworks and project management. Stillwater, OK: New Forums Press.

Martin, A. M., \& Hand, B. (2009). Factors affecting the implementation of argument in the elementary science classroom. A longitudinal case study. Research in Science Education, 39(1), 1738.

Massey, S. L., Pence, K. L., Justice, L. M., \& Bowles, R. P. (2008). Educators' use of cognitively challengingquestions in economically disadvantaged preschool classroom contexts. Early Education and Development, 19(2), 340360.

Michael 2012). "Analysis". The stanford encyclopedia of philosophy. Michael Beaney. Retrieved 23 May2012.

Myhill,D. Jones,S \& Rosemary Hopper,R. (2006).Talking, Learning Effective Talk in the Primary Classroom. Open University Press: Berkshire.

Mohr, K.J., \& Mohr, E.S. (2007). Extending English-language learners' classroom 
interactions using the response protocol. The Reading Teacher, 60(5), 440450.

Monk, M., \& Osborne, J. (Eds.). (2000). Good practice in science teaching: what research has to say. Buckingham: Open University Press.

Mortimer, E., \& Scott, P. (2003). Meaning making in secondary science classrooms. Maidenhead: Open University Press.

Ogu, U., \& Schmidt, S. R. (2009). Investigating rocks and sand. Young Children, 64(1), 12-18.

Ping Shen, (2012). A case study of teacher's questioning and students' critical thinking in college EFL reading classroom, International Journal of English Linguistics Vol. 2, No. 1; February 2012

van de Pol, J., Volman, M., \& Beishuizen, J. (2010). Scaffolding in teacher-student interaction: A decade of research. Educational Psychology Review, 22, 271296.
Walsh, J. A., \& Sattes, B. D. (2005). Quality questioning: researchbased practice to engage every learner. London: Corwin Press.

Wilen, William. 1987. Questions, questioning techniques, and effective

teaching. Washington, DC: National Education Association.

Wragg, E. C., \& Brown, G. (2001). Questioning in the primary school. London: Routledge Falmer. 
